Tersedia online di: http://ejournal-balitbang.kkp.go.id/index.php/JP
e-mail:jurnalpari@gmail.com
JURNAL PARI

\title{
PEMAHAMAN PEJABAT FUNGSIONAL PUSTAKAWAN PDII LIPI TERHADAP REFORMASI BIROKRASI
}

\author{
Yupi Royani dan Rochani Nani Rahayu \\ Pusat Data dan Dokumentasi IImiah LIPI, Lembaga IImu Pengetahuan Indonesia \\ JL. Gatot Subroto, Kuningan Barat, Jakarta Selatan \\ Diterima tanggal : 14 Agustus 2019 Diterima setelah perbaikan : 26 September 2019 \\ disetujui terbit : 12 November 2019
}

\begin{abstract}
ABSTRAK
Pemahaman Pejabat Fungsional Pustakawan PDII LIPI tentang Reformasi Birokrasi (RB) diteliti menggunakan metode survey melalui pertanyaan yang disampaikan dalam kuesioner kepada 30 orang responden. Penelitian ini bertujuan untuk mengetahui pemahaman RB khususnya definisi, tujuan, dan manfaat, serta slogan dan tujuan dibuatnya slogan. Kuesioner yang kembali sebanyak 26 buah, setelah dilakukan pengolahan data secara kualitatif didapatkan hasil sbb. Responden yang "tahu" tentang definisi RB sebanyak $84,60 \%$, tujuan RB yang tahu sebanyak $88,40 \%$, slogan RB sebesar $46,15 \%$, tujuan slogan sebesar 53,85\%, manfaat RB 30,77\%. Kesimpulan penelitian adalah pejabat fungsional pustakawan PDII LIPI mengetahui definisi dan tujuan reformasi birokrasi, namun lebih dari separo $(69,20 \%)$ kurang mengetahui tentang manfaat reformasi birokrasi. Hampir separo dari pejabat fungsional pustakawan PDII LIPI belum mengetahui keberadaan slogan/ motto / reformasi, beserta tujuan dibuatnya slogan tersebut. Disarankan agar dilakukan sosialisasi serta evaluasi secara berkesinambungan.
\end{abstract}

\section{KATA KUNCI : Reformasi birokrasi; Pejabat Fungsional Pustakawan; Slogan; PDII LIPI.}

\begin{abstract}
Understanding of Functional Officers of the PDII LIPI Librarian on Bureaucratic Reform (RB) asked to use the survey method through the questions submitted in the questionnaire to 30 respondents. The purpose of this study was to find out an understanding of the resolution, goals, and benefits, as well as the slogans and objectives they made. Questionnaires were returned as many as 26 pieces, after processing data qualitatively, the following results were obtained. Respondents who "knew" about $R B$ resolution were $84.60 \%$, the purpose of $R B$ who knew was $88.40 \%$, the slogan of $R B$ was $46.15 \%$, the goal of the slogan was $53.85 \%$, the Benefits of $R B$ were $30.77 \%$. The conclusions of the study were librarian functional officials in the resolution and objectives of bureaucratic reform, but more than half (69.20\%) were unaware of the benefits of bureaucratic reform. Almost separated from functional officials, the librarian PDII LIPI has not found the slogan / motto / reform, along with the purpose of making the slogan. It is hoped that ongoing socialization and evaluation will be carried out.
\end{abstract}

\section{KEYWORDS: Bureaucratic Reformation; Librarian Functional Officials; Slogan; LIPI PDII}




\section{PENDAHULUAN}

\section{Latar Belakang}

Reformasi Birokrasi adalah amanat dari Peraturan Menteri Pendayagunaan Aparatur Negara dan Reformasi Birokrasi Nomor 11 Tahun 2015 tentang Road Map Reformasi Birokrasi 2015-2019 memberikan indikasi kuat perubahan arah kebijakan dan pendekatan Reformasi Birokrasi Nasional (Atmaji, D.W; 2016). Reformasi birokrasi yang dimulai pada (2005-2009) dan tahap pertama program reformasi birokrasi nasional (2010-2014), maka arah kebijakan reformasi birokrasi adalah pembentukan infrastruktur birokrasi nasional.

Pusat Dokumentasi dan Informasi IImiah Lembaga IImu Pengetahuan Indonesia (PDII -LIPI) merupakan salah satu unit kerja eselon dua yang berada di bawah Lembaga IImu Pengetahuan Indonesia. Adapun tugas utama PDII LIPI adalah melakukan dokumentasi serta memberikan layanan informasi ilmiah bagi pemustaka terutama adalah para peneliti di lingkungan LIPI serta masyarakat luas pada umumnya.

Sehubungan dengan tugas tersebut, maka PDII LIPI dituntut bekerja lebih profesional dalam memberikan layanan kepada pemustaka serta melakukan dokumentasi dalam bentuk repositori lembaga.

Seperti diketahui sampai dengan periode 2014 Struktur Organisasi dan Tata Kerja yang dilaksanakan oleh PDII LIPI adalah mengikuti Surat Keputusan Kepala LIPI Nomor: 1151/M/2001 tanggal 5 Juni 2001 tentang Organisasi dan TataKerja LIPI. Akan tetapi di dalam struktur organisasi tersebut dijumpai permasalahan pekerjaan yang dirasakan tumpang tindih antar bidang atau sub bidang, serta ketidaksesuaian penempatan unit eselon IV.

Hal tersebut diduga berpengaruh terhadap persepsi sivitas PDII LIPI terhadap Reformasi Birokrasi yang meliputi definisi, tujuan, manfaat dan slogan RB PDII. Indikasi yang mendukung pernyataan tersebut antara lain adalah hasil penelitian yang dilakukan oleh Rochani Nani Rahayu dan Wahid Nashihudin tentang Pemahaman Staf PDII LIPI terhadap Reformasi Birokrasi yang dilakukan pada tahun 2012. Kesimpulan dari hasil penelitian menunjukkan bahwa dari keseluruhan sivitas PDII LIPI sudah mengetahui definisi dan tujuan diadakannya Reformasi Birokrasi, namun kurang mengetahui manfaat dari Reformasi Birokrasi. Sebagian besar sivitas PDII tidak mengetahui slogan Reformasi Birokrasi serta tujuan dibuatnya slogan tersebut.
Oleh karena itu, untuk mengatasi masalah tersebut salah satu upaya yang dilakukan PDII LIPI adalah dengan melakukan perubahan manajemen, melalui perubahan organisasi dari struktur versi Surat Keputusan Kepala LIPI Nomor : 1151/M/2001 tanggal 5 Juni 2001 tentang Organisasi dan Tata Kerja LIPI menjadi struktur organisasi versi Peraturan Kepala LIPI No 1 Tahun 2014, tentang Organissi dan Tata Kerja; dengan harapan agar kinerja yang telah ditetapkan dapat dilaksanakan dengan baik berlandaskan Reformasi Birokrasi.

\section{Rumusan Masalah}

Setelah dilakukan restrukturisasi organisasi PDII LIPIdari yang tercantum dalam Surat Keputusan Kepala LIPI Nomor : 1151/M/2001 tanggal 5 Juni 2001 tentang Organisasi dan Tata Kerja LIPI, menjadi struktur yang tercantum dalam Peraturan Kepala LIPI No 1 Tahun 2014, apakah sivitas PDII khususnya Pejabat Fungsional Pustakawan sudah lebih memahami tentang persepsi Reformasi Birokrasi dalam hal definisi, tujuan, slogan dan manfaatnya serta upaya yang sebaiknya dilakukan agar pelaksanaan Reformasi Birokrasi berjalan optimal? Dengan demikian penelitian ini bertujuan untuk mengetahui:

a. Pemahaman pejabat Pejabat Fungsional Pustakawan PDII LIPI tentang konsep Reformasi Birokrasi yang sudah dilaksanakan meliputi definisi, tujuan, slogan dan manfaat Reformasi Birokrasi.

b. Hal yang harus dilakukan agar Reformasi Birokrasi dapat berjalan dengan baik.

\section{TINJAUAN PUSTAKA}

\section{Reformasi Birokrasi}

Reformasi birokrasi yang sedang dan telah dilaksanakan oleh pemerintah Republik Indonesia baik di pemerintah pusat maupun pemerintah daerah adalah tuntutan perubahan organisasi dalam segala aspek, meliputi aspek politik, ekonomi, sosial dan hukum. Adapun reformasi diartikan sebagai suatu sistem dan budaya politik yang bersifat paternal, otokratik, monolitik, sentralitik, dengan regimentasi kuat serta intervensi pemerintah yang acapkali bersifat distortif. Beberapa sifat distortif dianalogikan dengan sifat koruptif, kolusi, kronisme dan nepotisme. Sistem tersebut diharapkan berubah menjadi sistem yang lebih terbuka, demokratis, egalitarian, toleran, dengan pemeran utama ekonomi adalah masyarakat dalam sistem pasar yang lebih fair /adil (Tjokroamidjojo: 2001). 
Reformasi birokrasi merupakan upaya pemerintah untuk meningkatkan kepercayaan publik kepada pemerintah. Ketidakefisienan serta ketidakefektifan pelayanan publik kepada masyarakat merupakan sumber utama ketidakpercayaan publik kepada pemerintah (Vigoda-Gadot dan Mizrahi; dalam Atmaja, D.W: 2016).

Reformasi birokrasi sebagai upaya untuk mewujudkan pemerintahan yang bersih, akuntabel, efektif, efisien, dan memberikan pelayanan berkualitas juga memiliki tujuan membangun kepercayaan publik kepada pemerintah. Sebaliknya, kepercayaan publik juga dapat memberikan manfaat bagi kepemerintahan, antara lain mengurangi biaya transaksi dalam penyelenggaraan pemerintahan, meningkatkan legitimasi kebijakan yang diambil pemerintah, dan meningkatkan modal sosial utamanya dalam hubungan antara pemerintah dan masyarakat (Dwiyanto: dalam Atmaja, D.W: 2016).

Program Reformasi Birokrasi yang diprakarsai Kabinet Kerja Presiden dan Wakil Presiden Joko Widodo, melalui gerakan Revolusi Mental Aparatur Sipil Negara dengan melakukan Reformasi Birokrasi yaitu; reformasi mindset (cara pikir), reformasi struktur agar lebih simple, reformasi culture (budaya kerja dan perilaku, serta reformasi sistem koordinasi yang lebih terintegrasi.

Suatu pemerintahan yang dinamis adalah pemerintahan yang memiliki birokrasi yang berwawasan ke depan, yang mampu mempelajari dan mengevaluasi kekurangan-kekurangannya di masa lampau, dan mampu melakukan komunikasi dan kerja-kerja lintas sektoral sehingga terbangun sebuah sistem birokrasi yang responsif dan tanggap mengikuti dinamika masyarakatnya. Jadi kalau masyarakatnya dinamis, pemerintahannya pun harus dinamis (Chrisnandi, Y: 2015).

Reformasi birokrasi harus diikuti oleh pola pikir Aparatur Sipil Negara harus berubah terlebih saat ini sudah ada Undang-Undang Aparatur Sipil Negara (ASN) adalah sebuah panduan penataan sistem kepegawaian yang modern dan visioner. Sudah mengakomodir berbagai pemikiran, kehendak dan harapan dari masyarakat luas, dari kalangan akademisi, dari praktisi bahkan secara internal dari para aparatur pemerintah yang bekerja dalam sistem pemerintahan, (Chrisnandi, Y: 2015).

Di dalam Undang - Undang Aparatur Sipil Negara dijelaskan bahwa aparatur sipil negara terdiri dari dua entitas. Entitas yang pertama pegawai negeri sipil (PNS) yang di dalam proses penempatannya diatur oleh UU ASN, ada usia minimumnya (19 tahun), usia maksimum (35 tahun), ada perjanjian kerja dan seterusnya lewat sebuah proses seleksi Calon Pegawai Negeri Sipil (CPNS). Sementara yang satunya adalah pegawai pemerintah dengan perjanjian kerja. Dia tidak ada minimalnya tidak ada maksimalnya, tidak melalui sebuah proses tes CPNS (Chrisnandi, Y: 2015).

Nilai positif dari kondisi di atas dapat memberikan peringatan kepada PNS apabila tidak meningkatkan kemampuannya, tidak mau belajar, tidak mau mengikuti perkembangan zaman dan kebutuhan masyarakat, maka akan ada orang lain yang mengisi jabatan - jabatan yang diperlukan dalam struktur kepegawaian pemerintah. Hal ini menjadi peringatan sekaligus tantangan bagi para PNS, jika mereka wajib belajar, meningkatkan kualitas maupun profesionalisme agar menjadi PNS unggul.

Adapun dalam masyarakat yang terbuka, kondisi ini memberikan kesempatan yang seluas-luasnya kepada siapa saja anggota masyarakat yang memiliki kemampuan sesuai dengan kebutuhannya dan kemampuannya mengungguli kapasitas yang dimiliki oleh pegawai negeri sipil, bisa menjadi pejabat-pejabat pemerintah.

Positif yang ketiga, akan terjadi kompetisi antara PNS dan non PNS sehingga mereka yang terbaiklah yang dapat duduk di pemerintahan (Chrisnandi, Y: 2015). Dengan demikian orang terbaik untuk mengelola pemerintah bisa dari orang di luar sistem pemerintahan, sebagai contoh, ada ahli SDM, kenapa tidak dicoba. Misalnya ada ahli dari City Bank, ahli keuangan, ditarik jadi Dirjen Anggaran, tokoh - tokoh terbaik dari NU maupun Muhammadiyah dapat ditarik untuk menjadi Dirjen Bimas Islam; dll (Chrisnandi, Y: 2015).

\section{Pusat Dokumentasi dan Informasi IImiah}

Seperti diuraikan di dalam pendahuluan di atas, di dalam upaya mengimplementasikan Reformasi Birokrasi di PDII LIPI, telah dilakukan perubahan struktur organisasi agar dapat dengan optimal menjalankan Reformasi Birokrasi. Akan tetapi sesungguhnya PDII LIPI telah beberapa kali mengalami perubahan organisasi sejak berdirinya yaitu pada 1 Juni 1965.

Diawali dengan terbentuknya Bagian Dokumentasi, seiring dengan berdirinya Majelis IImu Pengetahuan Indonesia pada tahun 1956. Sesuai dengan perkembangan jaman, pada tanggal 1 Juni 1965, Bagian Dokumentasi tersebut berubah menjadi 
Pusat Dokumentasi IImiah Nasional berdasarkan Surat Keputusan Menteri Research Nasional Nomor: 107/M/Kpts/Str/65.

Pada tahun 1987 nama Pusat Dokumentasi Ilmiah Nasional berubah menjadi Pusat Dokumentasi dan Informasi IImiah (PDII). Perubahan struktur organisasi terjadi kembali pada tahun 2001, dengan diterbitkannya Surat Keputusan Menteri
Pendayagunaan Aparatur Negara Nomor: 138/M.PAN /5/2001 tanggal 31 Mei 2001, tentang Restrukturisasi. Surat Keputusan ini diikuti oleh Surat Keputusan Kepala Lembaga IImu Pengetahuan Indonesia (LIPI) Nomor : 1151/M/2001 tanggal 5 Juni 2001 tentang Organisasi dan Tata Kerja LIPI. Struktur organisasi PDII LIPI secara lengkap dapat dilihat pada gambar di bawah ini. (Rahayu; RN: 2016).

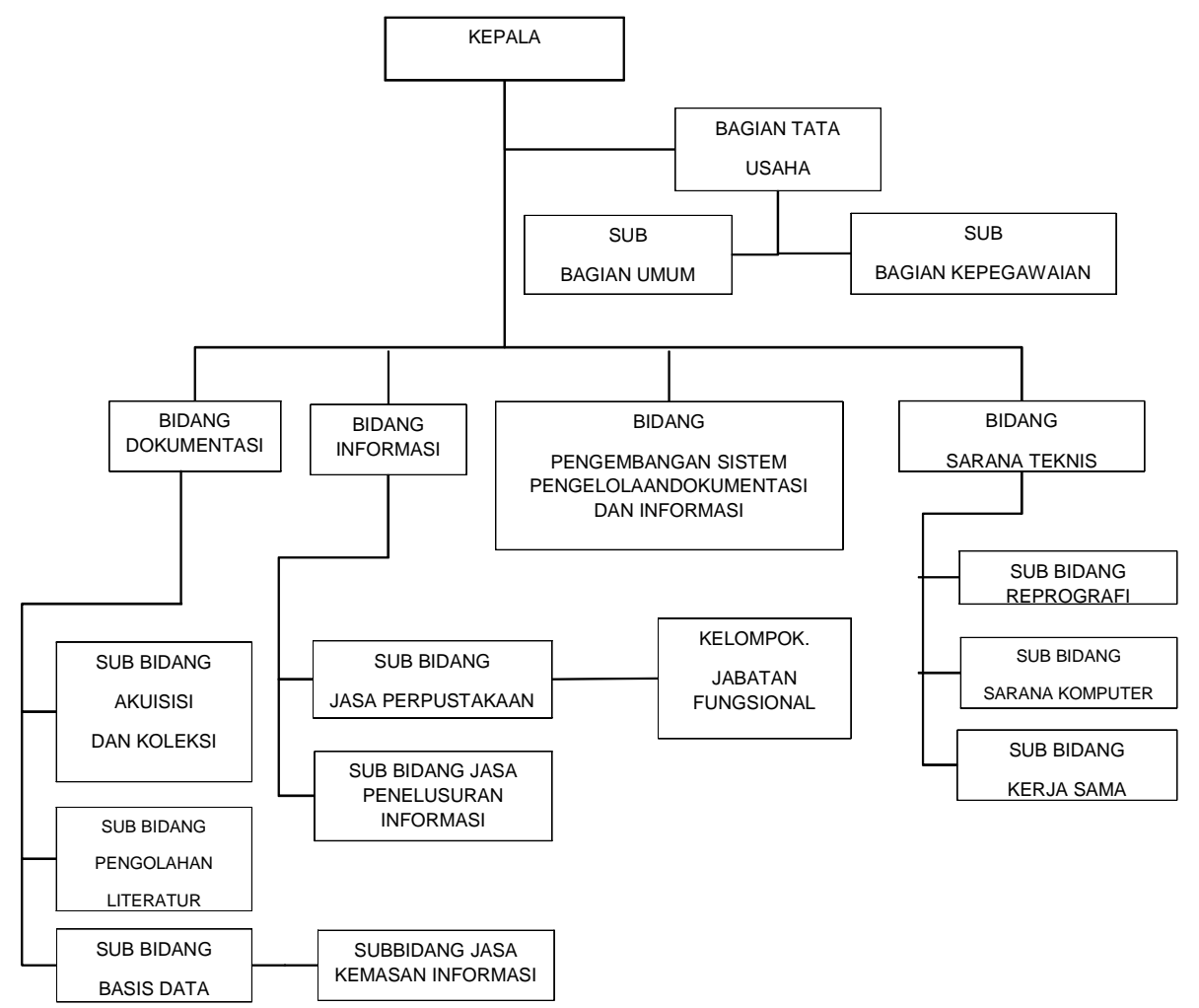

Gambar 1. Struktur Organisasi Pusat Dokumentasi Dan Informasi IImiah Menurut Surat Keputusan LIPI Nomor $: 1151 / \mathrm{M} / 2001$

\section{a. Tugas dan Fungsi}

Sesuai SK Kepala LIPI NO.1151/M/2001 tanggal 5 Juni 2001, Pusat Dokumentasi dan Informasi Ilmiah (PDII) mempunyai tugas melaksanakan penyiapan perumusan kebijakan, penyusunan pedoman, pemberian bimbingan teknis, penyusunan rencana dan program, pelaksanaan penelitian, pelayanan serta evaluasi dan penyusunan laporan di bidang dokumentasi dan informasi. Dalam melaksanakan tugas sebagaimana tersebut di atas, PDII menyelenggarakan fungsi sebagai berikut:

1. Penyiapan bahan perumusan kebijakan di bidang dokumentasi dan informasi ilmiah. Penyusunan pedoman, pemberian bimbingan teknis, pelaksanaan dan pelayanan di bidang dokumentasi dan informasi ilmiah;

2. Penyusunan rencana, program, serta pelaksanaan penelitian di bidang dokumentasi dan informasi ilmiah;

3. Pengelolaan sarana teknis dokumentasi dan informasi ilmiah;
4. Evaluasi dan penyusunan laporan penelitian dan pelayanan dokumentasi dan informasi ilmiah;

Perubahan terakhir struktur organisasi PDII LIPI menyesuaikan dengan Peraturan Kepala LIPI No 1 Tahun 2014, tentang Organisasi dan Tata Kerja, dengan tugas fungsi sebagai berikut:

1. Penyusunan kebijakan teknis, rencana, dan program pengkajian dan penelitian di bidang dokumentasi dan informasi;

2. Pendokumentasian informasi ilmiah;

3. Penyediaan akses ke informasi ilmiah;

4. Pengkajian dan penelitian di bidang dokumentasi dan informasi;

5. Pemantauan, evaluasi, dan pelaporan pendokumentasian informasi ilmiah, penyediaan akses ke informasi ilmiah, pelaksanaan pengkajian dan penelitian dibidang dokumentasi dan informasi;

6. Pelaksanaan urusan tata usaha. 


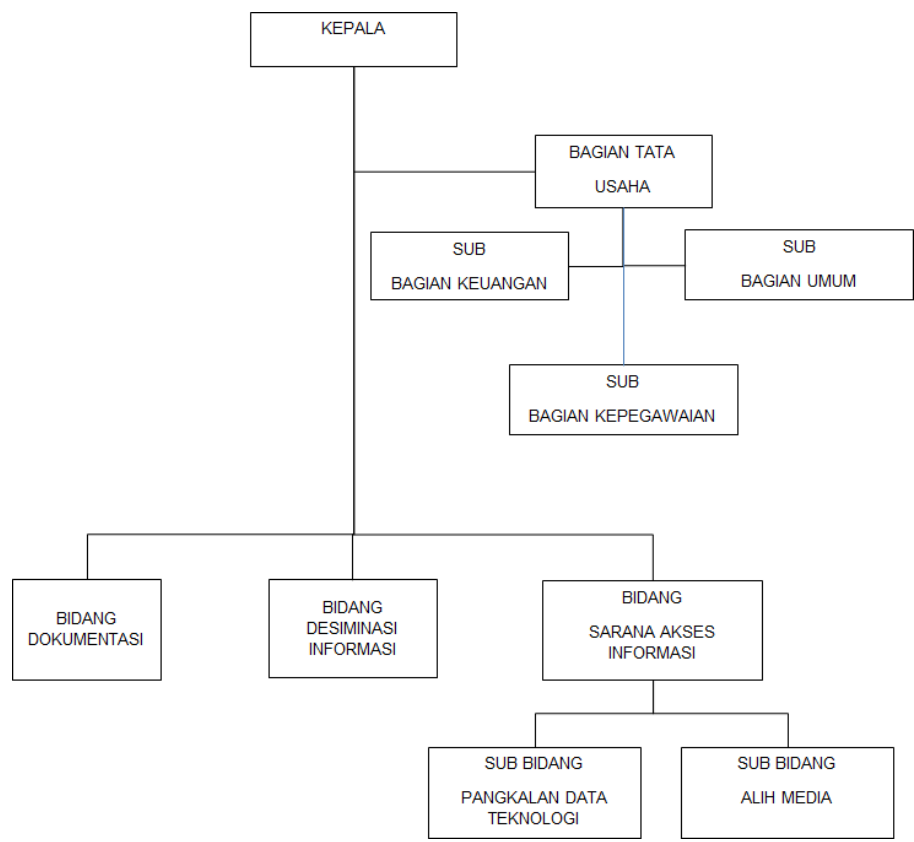

Gambar 2. Struktur organisasi PDII menurut Peraturan Kepala LIPI No 1 Tahun 2014, tentang Organisasi dan Tata Kerja

Apabila dicermati struktur organisasi berdasarkan Surat Keputusan LIPI Nomor: 1151/M/2001+ dengan struktur organisasi berdasarkan Peraturan Kepala LIPI No 1 Tahun 2014, tentang Organissi dan Tata Kerja, dapat diketahui bahwa jumlah eselon tiga dari yang semula berjumlah lima yaitu Bagian Tata Usaha, Bidang Dokumentasi, Bidang Informasi, Bidang Pengelolaan Sistem Dokumentasi dan Informasi, dan Bidang Sarana Teknik;

1. Menjadi empat eselon tiga yang terdiri atas: Bagian Tata Usaha, Bidang Dokumentasi, Bidang Informasi dan Bidang Sarana Akses Informasi.

2. Jumlah eselon empat dari semula sebelas sub bidang yaitu, Sub Bagian Umum, Sub Bagian Kepegawaian, Sub Bidang Akuisisi dan Koleksi, Sub Bidang Pengolahan Literatur, Sub Bidang Basis Data, Sub Bidang jasa Perpustakaan, Sub Bidang Jasa Penelusuran, Sub Bidang Jasa
Kemasan Informasi, Sub Bidang Reprografi, Sub Bidang Sarana Komputer dan Sub Bidang Kerjasama; menjadi lima sub bidang yaitu ; Sub Bagian Keuangan, Sub Bagian Umum, Sub Bagian Kepegawaian.

3. Adanya pengurangan pejabat struktural diharapkan dapat mempermudah serta mempercepat koordinasi dari atasan ke bawahan sehingga segala sesuatu yang berkaitan dengan pergerakan organisasi menjadi semakin lancar.

b. Sumber Daya Pejabat Fungsional Pustakawan

Data dari Sub Bagian Kepegawaian menunjukkan bahwa SDM Pejabat Fungsional Pustakawan hingga Oktober 2018 dapat dilihat pada tabel 1 dan tabel 2 berikut.

Tabel 1. Pejabat Fungsional Pustakawan Keahlian di PDII LIPI (Oktober 2018)

\begin{tabular}{|l|c|c|}
\hline \multicolumn{1}{|c|}{ Jabatan } & Jumlah & Persentase (\%) \\
\hline Pustakawan Ahli Utama & 1 & 5 \\
\hline Pustakawan Ahli Madya & 7 & 35 \\
\hline Pustakawan Ahli Muda & 7 & 35 \\
\hline Pustakawan Ahli Pertama & 5 & 100 \\
\hline \multicolumn{1}{|c|}{ Jumlah } & 20 & \\
\hline
\end{tabular}

Diolah dari data subbagian kepegawaian PDII LIPI 
Tabel 2. Pejabat Fungsional Pustakawan Keterampilan di PDII LIPI (Oktober 2018)

\begin{tabular}{|c|c|c|}
\hline \multicolumn{1}{|c|}{ Jabatan } & Jumlah & Persentase (\%) \\
\hline Pustakawan - Terampil & 3 & 30 \\
\hline Pustakawan Mahir & 1 & 10 \\
\hline Pustakawan Penyelia & 6 & 60 \\
\hline Jumlah & 10 & 100 \\
\hline
\end{tabular}

Diolah dari data subbagian kepegawaian PDII LIPI

Menurut data dari Sub Bagian Kepegawaian, jumlah seluruh pegawai PDII LIPI hingga Oktober 2018 adalah 102 orang, maka jumlah Pejabat Fungsional Pustakawan adalah sekitar 30\% dari seluruh populasi pegawai PDII LIPI.

\section{METODOLOGI PENELITIAN}

\subsection{Metodologi}

Penelitian yang dilakukan bersifat kualitatif, menurut Sumanto (2005) jenis penelitian kualitatif adalah jenis penelitian dengan pengumpulan data yang diharapkan dapat memberikan gambaran atau penegasan suatu konsep maupun gejala sekaligus menjawab berbagai pertanyaan yang berhubungan dengan status obyek penelitian.

Data penelitian kualitatif berbentuk bukan angka namun berupa kalimat - kalimat, foto, maupun rekaman suara serta gambar gambar (Risnarto, 2004).

Penelitian Pemahaman Pejabat Fungsional Pustakawan PDII LIPI dilakukan menggunakan metode survei. Adapun data kualitatif yang diperoleh berupa berupa jawaban pertanyaan yang dicantumkan di dalam kuesioner. Sehingga hasil yang diperoleh merupakan gambaran apa adanya dari objek yang diteliti.

\subsection{Responden Penelitian}

Pejabat Fungsional Pustakawan di PDII LIPI yang ditugaskan di Bidang Diseminasi Informasi. Bidang Dokumentasi dan Bidang Sarana Akses Informasi, dipilih sebagai responden. Disebarkan sebanyak 30 kuesioner kepada mereka, yang berisi profil responden dan obyek masalah penelitian.

\subsection{Pengumpulan Data}

Dari 30 buah kuesioner yang telah disebar, yang kembali sebanyak 26 buah. Hal ini diduga akibat kesibukan yang harus mereka jalankan, sehingga tidak sempat untuk mengisi serta menyerahkan kepada Tim Peneliti. Pertanyaan tentang obyek penelitian yang diberikan kepada responden terdiri atas dua pernyataan yaitu " tahu" dan "tidak tahu". Apabila responden menjawab "tahu" maka ybs wajib memberikan penjelasan alasannya, dan jika "tidak tahu" maka responden tidak perlu memberikan penjelasan. Dan apabila responden menjawab "tahu" maka mendapatkan nilai satu (1), dan jika tidak tahu mendapatkan nilai nol (0). Apabila resonden menjawab "tahu" namun tidak memberikan penjelasan maka dianggap tidak tahu dan mendapat nilai nol (0).

Jawaban setiap responden dihitung dengan persentase (\%) normal, yaitu dengan cara menjumlahkan jawaban responden dibagi dengan jumlah keseluruhan responden:

$$
\Sigma=\frac{\text { Jumlah nilai jawaban responden }}{\text { Jumlah responden }} \times 100 \%
$$

Berdasarkan rumus di atas dapat diketahui jawaban yang disampaikan oleh para responden penelitian (lampiran 2).

\subsection{Pengolahan Data}

Data yang dikumpulkan dari kuesioner, selanjutnya diolah dengan cara sebagai berikut:

a. Tabulasi: data jawaban dari kuesioner dikelompokkan sesuai dengan bahasan Penelitian dalam format tabel, yang berisikan profil responden dan tabel tentang obyek masalah penelitian.

b. Reduksi; data yang sudah dikelompokkan selanjutnya direduksi dengan cara meringkas dan menghilangkan data yang dianggap memiliki arti sama dengan jawaban sebelumnya.

c. Penyajian: data yang sudah direduksi selanjutnya disusun secara sistematis. Data tentang profil responden disusun dalam bentuk tabel, dan data obyek penelitian disajikan dalam bentuk persentase (\%) jawaban responden disertai penjelasannya (lampiran 2 dan 3)

d. Penyusunan kesimpulan: kesimpulan disusun berdasarkan hasil pembahasan dari data yang ada. 


\section{HASIL DAN PEMBAHASAN}

\subsection{Profil Responden}

Responden penelitian adalah seluruh Pejabat Fungsional Pustakawan yang mengembalikan kuesioner dan disusun berdasarkan jenis kelamin, tingkat Pendidikan dan masa kerja.

\section{a. Responden Berdasarkan Jenis Kelamin}

Berdasarkan data yang terkumpul diketahui bahwa dari sejumlah 26 orang responden terdapat 15 orang berjenis kelamin laki - laki $(57,69 \%)$ dan responden yang berjenis kelamin perempuan berjumlah 11 orang (42,31\%). Supaya lebih jelas dapat dilihat dari Tabel 3 berikut ini.

Tabel 3. Responden berdasarkan jenis kelamin

\begin{tabular}{|c|c|c|}
\hline Jenis kelamin & Jumlah & Persentase (\%) \\
\hline Laki - laki & 15 & 57,69 \\
\hline Perempuan & 11 & 42,31 \\
\hline Jumlah & $\mathbf{2 6}$ & $\mathbf{1 0 0}$ \\
\hline
\end{tabular}

\section{b. Responden Berdasarkan Tingkat Pendidikan}

Apabila dilihat dari jenjang pendidikan, maka terdapat empat jenjang pendidikan dimulai dari tingkat SMA, D3, S1 dan S2. Berdasarkan data dari Tabel 4 di bawah ini dapat diketahui bahwa responden dengan tingkat pendidikan SMA sebanyak 8 orang $(30,77 \%)$, kemudian D3 sebanyak 2 orang $(7,70 \%)$, S1 12 orang $(46,15 \%)$ dan S2 berjumlah 4 orang (15,38\%).

Tabel 4. Responden berdasarkan tingkat Pendidikan

\begin{tabular}{|c|c|c|}
\hline Pendidikan & Jumlah & Persentase (\%) \\
\hline SMA & 8 & 30,77 \\
\hline D3 & 2 & 7,70 \\
\hline S1 & 12 & 46,15 \\
\hline S2 & 4 & 15,38 \\
\hline Jumlah & $\mathbf{2 6}$ & $\mathbf{1 0 0}$ \\
\hline
\end{tabular}

c. Responden Berdasarkan Masa Kerja

Untuk melihat masa kerja dari para responden maka Tabel 5 berikut ini dapat digunakan sebagai acuan. Masa kerja responden dibuat dalam rentang waktu per lima tahun, masing - masing dalam interval 0 - 5 tahun terdapat 5 orang $(19,23 \%), 6-10$ tahun diketahui sebanyak 5 orang $(19,23 \%)$, selanjutnya interval $11-15$ tahun terdapat sebanyak 1 orang (3,84\%). Responden dengan masa kerja 16 -20 tahun sebanyak 3 orang (11,54\%) serupa dengan responden dengan masa kerja 21-25 tahun. Berikutnya mereka yang memiliki masa kerja 26 -
30 tahun terdapat sebanyak 7 tahun dan responden dengan masa kerja > 30 tahun ditemukan sebanyak 2 orang (7,70\%).

Tabel 5. Responden berdasarkan masa kerja

\begin{tabular}{|c|c|c|}
\hline Masa kerja (th) & Jumlah & Persentase (\%) \\
\hline $0-5$ & 5 & 19,23 \\
\hline $6-10$ & 5 & 19,23 \\
\hline $11-15$ & 1 & 3,84 \\
\hline $16-20$ & 3 & 11,54 \\
\hline $21-25$ & 3 & 11,54 \\
\hline $26-30$ & 7 & 26,92 \\
\hline$>30$ & 2 & 7,70 \\
\hline Jumlah & $\mathbf{2 6}$ & $\mathbf{1 0 0}$ \\
\hline
\end{tabular}

\subsection{Pemahaman Reformasi Birokrasi}

\section{a. Definisi Reformasi Birokrasi}

Dari sejumlah 26 responden yang mengembalikan kuesioner diketahui bahwa mereka yang menyatakan "tahu "akan definisi Reformasi Birokrasi berjumlah 25 orang, namun setelah diperiksa ternyata dijumpai sebanyak 1 orang tidak memberikan penjelasan tentang arti / definisi Reformasi Birokrasi dan 1 orang memberikan penjelasan yang tidak tepat dan 2 orang menyatakan "tidak tahu". Sehingga 4 orang mendapatkan nilai 0 , dan 22 orang mendapatkan nilai 1. Sehingga persentase responden yang menyatakan "tahu" akan definisi Reformasi Birokrasi adalah $84,61 \%$. Dengan demikian lebih dari setengah populasi responden mengetahui definisi Reformasi Birokrasi sekaligus menjelaskan dalam bentuk kalimat. Beberapa kalimat dari responden tentang definisi Reformasi Birokrasi adalah sebagai berikut:

1. Reformasi Birokrasi berkaitan dengan perubahan tata organisasi seperti struktur dan profesionalitas SDM, perbaikan kinerja (anti korupsi, dll) proses bisnis semakin disederhanakan, lebih terbuka dll.

2. Reformasi Birokrasi pada hakekatnya merupakan upaya untuk melakukan pembaharuan dan perubahan mendasar setiap sistem penyelenggaraan pemerintah terutama menyangkut aspek - aspek kelembagaan (organisasi), ketatalaksaan (business processes) dan sumber daya aparatur.

3. Reformasi Birokrasi adalah langkah-langkah strategis untuk membangun aparatur negara agar lebih berdayaguna dan berhasil guna dalam mengemban tugas umum pemerintahan dan pembangunan nasional.

4. Reformasi Birokrasi adalah perubahan tata kelola penyelenggaraan pemerintahan yang lebih baik/ layanan berkualitas. 
Apabila mengacu defnisi yang diberikan oleh KemenPANRB maka yang dimaksud dengan Reformasi Birokrasi pada hakikatnya merupakan upaya untuk melakukan pembaharuan dan perubahan mendasar terhadap sistem penyelenggaraan pemerintahan terutama menyangkut aspek-aspek kelembagaan (organisasi), ketatalaksanaan (business prosess) dan sumber daya manusia aparatur. (http.www.menpan.go.id/site/reformasi-birokrasi/ makna-dan-tujuan).

Mencermati ke empat kalimat diatas, maka semua kata kunci yang tercantum dalam definisi KemenPANRB disitir dalam empat kalimat di atas, dengan demikian dapat dikatakan bahwa para responden mengerti dan memahami arti dari Reformasi Birokrasi.

\section{b. Tujuan Reformasi Birokrasi}

Pertanyaan ke dua tentang tujuan Reformasi Birokrasi dijawab "tahu" oleh sebanyak 22 orang responden dan sebanyak 3 orang menjawab "tidak tahu". Dengan demikian responden yang menjawab "tahu" dan memberikan penjelasan dan sesuai dengan jawaban yang diinginkan mendapatkan nilai 23 . Adapun responden yang menjawab "tidak tahu" mendapat nilai 0 . Maka persentase responden yang menjawab "tahu" adalah serupa dengan persentase yang menjawab "tahu' terhadap pertanyaan definisi Reformasi Birokrasi yaitu sebesar 88,46\%.

Namun ditemukan 1 responden yang menjawab "tahu" pada pertanyaan definisi Reformasi Birokrasi namun salah di dalam menjawab tujuan Reformasi Birokrasi. Jawaban responden tersebut adalah "Sejak tahun 2012 PDII memulai melaksanakan Reformasi Birokrasi'. Hal ini diduga responden tersebut kurang cermat di dalam menjawab pertanyaan antara tujuan Reformasi Birokrasi dan bukan kapan dimulainya Reformasi Birokrasi di PDII?

Berikut ini adalah beberapa jawaban dari responden yang menyatakan "tahu" akan tujuan Reformasi birokrasi.

1. Untuk mencipatakan birokrasi pemerintah yang profesional dengan karakteristik, berintegrasi, berkinerja tinggi, bebas dan bersih $\mathrm{KKN}$, mampu melayani publik, netral, sejahtera, berdedikasi, dan memegan teguh nilai-nilai dasar dan kode etik aparatur negara.

2. Untuk meningkatkan layanan kepada seluruh pihak melalui perbaikan sistem birokrasi yang ada.

3. PDII sebagai unit dibawah LIPI bisa menjadi garda terdepan dalam mendukung program pemerintah dalam mewujudkan unit kerja yang berintegritas, ilmiah dan unggul.

4. Untuk penataan sistem penyelenggaraan pemerintahan yang baik, efektif dan esifisen, sehingga dapat melayani masyarakat secara profesional- Untuk penataan sistem penyelenggaraan pemerintahan yang baik, efektif dan esifisen, sehingga dapat melayani masyarakat secara professional.

Reformasi birokrasi dilaksanakan dalam rangka mewujudkan tata kelola pemerintahan yang baik (good governance). Dengan kata lain, reformasi birokrasi adalah langkah strategis untuk membangun aparatur negara agar lebih berdaya guna dan berhasil guna dalam mengemban tugas umum pemerintahan dan pembangunan nasional. Selain itu dengan sangat pesatnya kemajuan ilmu pengetahuan, teknologi informasi dan komunikasi serta perubahan lingkungan strategis menuntut birokrasi pemerintahan untuk direformasi dan disesuaikan dengan dinamika tuntutan masyarakat. Sumber:https://www.menpan.go.id/site/ reformasi-birokrasi/makna-dan-tujuan.

Mencermati ke empat kalimat dari responden, nampaknya yang menonjol adalah kata pelayanan, aparatur sipil negara, perbaikan sistem brokrasi yang sesuai dengan kalimat dari MenPAN yang berbunyi. Reformasi birokrasi adalah langkah strategis untuk membangun aparatur negara agar lebih berdaya guna dan berhasil guna dalam mengemban tugas umum pemerintahan dan pembangunan nasional.; maka ke empat kalimat di atas dinyatakan masuk kriteria mengerti akan tujuan reformasi birokrasi.

\section{c. Slogan Reformasi Birokrasi}

Slogan Reformasi Birokrasi PDII LIPI ternyata hanya diketahui/ dikenal oleh sebanyak 15 orang responden adapun 11 orang responden menyatakan tidak tahu slogan Reformasi Birokrasai PDII. Dengan demikian persentase yang menjawab tahu adalah $42,31 \%$ dan yang tidak tahu berjumlah $57,69 \%$.

Slogan PDII LIPI tentang Reformasi Birokrasi adalah IDAMAN; IDAMAN: Iklhas, Disiplin, Amanah, Mandiri, Akuntabel, Normatif. Sumber: Poster PDII LIPI April 2018.

\section{d. Tujuan Slogan Reformasi Birokrasi}

Berdasarkan kuesioner yang masuk dapat diketahui bahwa responden yang menjawab "tahu" berjumlah 14 orang $(53,80 \%)$ dan yang menjawab tidak tahu sebesar 12 orang (46,15\%). Tujuan slogan diantaranya adalah 
1. Menyadarkan warga masyarakat.

2. Menyampaikan informasi tertentu.

3. Menghimbau orang lain.

4. Bertujuan mempengaruhi orang lain.

5. Bertujuan memotivasi orang lain.

Sumber: https://www.ruangguru.co.id/pengertianslogan-ciri-ciri-tujuan-macam-dan-contoh-sloganterlengkap/

Berikut ini adalah jawaban yang ditulis oleh responden:

1. Agar setiap individu mempunyai semangat dalam melaksanakan Reformasi Birokrasi yang tertanam dalam ingatan masing - masing tentang motto tersebut.

2. Untuk merubah budaya kerja yang ada menjadi lebih baik.

3. Agar setiap pegawai dalam bekerja selalu ikhlas tanpa pamrih, selalu disiplin dalam tugas, melaksanakan tugas dengan jujur, berintegritas, mandiri, dapat dipertanggungjawabkan, dan memperhatikan norma - norma yang berlaku.

4. Sivitas PDII diminta untuk menganut nilai - nilai yang mewakili (ikhlas, disiplin, amanah, mandiri, akuntabel dan normatif).

Berdasarkan penjelasan yang disampaikan oleh beberapa responden, walaupun secara umum sudah memenuhi unsur - unsur yang ada dalam tujuan pembuatan slogan Reformasi Birokrasi PDII, akan tetapi lebih banyak yang tidak menjawab maupun jawaban yang tidak sesuai dengan kriteria yang diinginkan.

\section{e. Manfaat Reformasi Birokrasi}

Reformasi Birokrasi akan merubah Sistem Manajemen Kinerja. Kini setiap unit instansi Pemerintah harus memiliki target hasil atau outcome yang manfaatnya dapat langsung dirasakan oleh masyarakat. Predikat keuangan ataupun hasil serapan tidak akan berarti jika tidak memberikan manfaat bagi masyarakat (MenPANRB; 2017)

Sumber:https://www.menpan.go.id/site/berita-terkini/ sistem-manajemen-kineria-kini-kerja-instansipemerintah-diukur-dari-hasil-outcomes-danmanfaatnya-bagi-masyarakat

Berdasarkan hasil kuesioner yang disampaikan oleh responden diketahui bahwa sebanyak 18 orang responden $(69,23 \%)$ menyatakan tidak tahu akan manfaat Reformasi Birokrasi dan sebannyak 8 orang $(30,77 \%)$ mengatakan "tahu" akan manfaat Reformasi Birokrasi. Berikut ini kalimat pernyataan dari responden yang mengetahui tentang manfaat Reformasi Birokrasi:
1. Supaya pelaksanaan kegiatan lebih transparan dan akuntabel sehingga meningkatkan pelayanan publik.

2. Dengan keberhasilan RB diharapkan dapat meningkatkan kinerja, produktivitas dan layanan PDII kepada masyarakat, masyarakat mendapatkan layanan prima dari PDII LIPI.

3. Akuntabel dan pelayanan prima.

4. Adanya pemahaman yang benar di semua level organisasi tentang perlunya peningkatan budaya kerja dan proses bisnis yang ada untuk memberikan layanan lebih baik kepada pengguna.

5. Berdasarkan ke empat kalimat pernyataan di atas, kata kunci yang muncul adalah pelayanan, dan hal ini sesuai dengan kriteria dari MenPANRB. Akan tetapi jumlah responden yang "tidak tahu" lebih banyak dibandingkan dengan responden yang "tahu". Ketidaktahuan itu diduga disebabkan oleh kekurangan sosialisasi tentang Reformasi Birokrasi.

4.3.Upaya yang Dilakukan Agar Reformasi Birokrasi Berjalan dengan Baik di PDII

a. Upaya Individu

Berikut ini adalah upaya yang dapat disumbangkan oleh individu Pejabat Fungsional Pustakawan:

1. Merubah pola kerja menjadi lebih berorientasi kepada kebutuhan pengguna, meningkatkan pelayanan kepada pemustaka dengan cara menerapkan SOP yang sesuai.

2. Komitmen dan berinovasi dalam peningkatan kinerja dan kualitas penanganan sesuai dengan peran dan tanggungjawabnya di PDII LIPI.

3. Memahami dan mengimplementasikan nilai - nilai budaya kerja organisasi.

4. Berintegritas, professional, bertanggungjawab terhadap profesi yang diemban.

5. Menaati apa yang sudah menjadi komitmen sivitas yang tercermin dalam fakta integritas, serta menganut nilai - nilai budaya kerja IDAMAN yang sudah dicanangkan PDII LIPI.

6. Bekerja sesuai Sasaran Kinerja Pegawai yang sudah ditetapkan oleh atasan serta mengembangkan kreativitas dan ide - ide terbaru guna meningkatkan kinerja.

b. Upaya Unit-Unit di PDII

Menurut responden upaya PDII yang harus dilakukan agar Reformasi birokrasi berjalan dengan baik adalah:

1. Membenahi organisasi supaya teroganisir dan terbuka. 
2. Melalui pelaksanaan program RB yang terkait dengan unit masing-masing, misalnya di TU dengan meningkatkan tata laksana, di SAI dengan meningkatkan sarana dan prasarana $\mathrm{TI}$, di desiminasi dengan peningkatan pelayanan, dan di dokumentasi dengan peningkatan kualitas cantuman.

3. Tidak membiasakan untuk bekerja/membangun tim dengan hanya menganggap hanya kelompokkelompok tertentu yang dapat melakukan pekerjaan, tetapi membagi rata semua pekerjaan, dan memberi kesempatan semua pekerja untuk melakukan pekerjaan terbaiknya. Karena untuk melakukan suatu pekerjaan mandiri, kreatif dan inovatif, tanpa adanya kesempatan juga tak berarti.

4. Terus memperbarui dan meningkatkan kinerja di bidang pelayanan serta menjaga kehormatan unit kerja.

\section{c. Saran Responden}

Beberapa saran responden yang perlu diperhatikan oleh PDII antara lain:

1. Pemerataan kesempatan serta komunikatif terhadap semua jajaran, kenali kekuatan dan kelemahan seluruh pegawai, pendekatan ke bawah bukan ke atas.

2. Semangat pimpinan sebagai role model dan meningkatkan kebersamaan dalam meningkatkan kinerja baik dalam konteks struktural, fungsional maupun kegiatan rutin dan kegiatan non rutin.

3. Reformasi Birokrasi masih perlu disosialisasikan kembali ke seluruh pegawai secara intensif agar lebih memahami pelaksanaan Reformasi Birokrasi.

4. Melakukan evaluasi minimal tiga bulan sekali tehadap nilai - nilai yang sudah dicanangkan.

5. Meningkatkan kerjasama, disiplin, dan prestasi kerja.

\section{KESIMPULAN DAN SARAN}

\section{KESIMPULAN}

Berdasarkan hasil dan pembahasan disimpulkan bahwa sebagian besar (> 80\%) Pejabat Fungsional Pustakawan PDII LIPI mengetahui definisi dan tujuan Reformasi Birokrasi, namun lebih dari separo $(69,20 \%)$ kurang mengetahui tentang manfaat Reformasi Birokrasi. Hampir separo dari Pejabat Fungsional Pustakawan PDII LIPI belum mengetahui keberadaan slogan/motto / Reformasi, beserta tujuan dibuatnya slogan tersebut. Kondisi tersebut serupa dengan kondisi pada saat organisasi PDII LIPI masih menganut Surat Keputusan Kepala LIPI NO.1151/M/ 2001 tanggal 5 Juni 2001 Tentang Organisasi dan Tata Kerja.

\section{SARAN}

Melakukan sosialisasi dan evaluasi tentang reformasi birokrasi kepada pustakawan secara berkesinambungan.

\section{DAFTAR PUSTAKA}

Arl / Humas MenPANRB. 2017. Sistem Manajemen Kinerja, Kini Kerja.

Atmaji, D.W. 2016. Relevansi dan Kontekstualisasi Strategi Reformasi Birokrasi 2015-2019. Diakses dari https://www.menpan.go.id/site/cerita-suksesrb/relevansi-dan-kontekstualisasi-strategireformasi-birokrasi-2015-2019-1. Pada tanggal7 November 2018.

Chrisnandi; Y. 2016. "Wawancara: Gerakan Reformasi Birokrasi Melalui Revolusi Mental". Media Informasi Kementerian Agama. Tahun XVIII Januari - Februari 2015, ed. 91, pp. 17 -20.

Menpan. 2017. Pemerintah Diukur Dari Hasil Outcomes dan Manfaatnya Bagi Masyarakat. Diakses dari https://www.menpan.go.id/site/berita-terkini/ sistem-manajemen-kineria-kini-kerja-instansipemerintah-diukur-dari-hasil-outcomes-danmanfaatnya-bagi-masyarakat. Pada tanggal 30 Oktober 2018.

Oke. 2018. Slogan: pengertian, ciri-ciri, tujuan, macam dan contoh slogan terlengkap. Diakses dari https://www.ruangguru.co.id/pengertian-slogan-ciri-ciri-tujuan-macam-dan-contoh-sloganterlengkap/. Pada tanggal 30 oktober 2018.

PDII LIPI. 2018. Poster Slogan Reformasi Birokrasi PDII LIPI. Jakarta: PDII-LIPI.

Peraturan Kepala LIPI No 1 Tahun 2014. Tentang Organissi dan Tata Kerja.

Rahayu, RN. (2016). "Profil Pusat Dokumentasi Dan Informasi IImiah". Jurnal Pustakawan Indonesia, Vol. 12 No. 1 , pp. $29-31$.

Sumanto. 2005. Metodologi Penelitian Sosial dan Pendidikan. Yogyakarta: Andi Offset.

Surat Keputusan Kepala LIPI NO.1151/M/2001 tanggal 5 Juni 2001 Tentang Organisasi dan Tata Kerja.

Tjokroamidjojo, B. 2001. Reformasi Administrasi Publik. Jakarta: Universitas. Krisnadwipayana. 